\title{
Real Wages and Unemployment
}

Economic activity in the United States has been on the upswing for well over two years. The economics of nearly all other industrialized countries are also advancing, although generally not quite as quickly as the American economy. In the decade prior to the current recovery, which began in 1982, the economies of the United States and Europe grew at similar rates. Despite this similarity in output growth, employment growth has been strong here but nonexistent in Europe.

\section{Output and unemployment}

The current expansion in the United States is leading the world recovery. Total output of goods and services in this country was about ten percent higher last year than in 1982, while the annual unemployment rate dropped from its postwar high of 9.7 percent to 7.5 percent over the same period. In the ten years since 1974, the U.S. economy generated 18 million new jobs. In the last two years alone, five and a half million people were added to payrolls.

Europe has fared less well. Since 1982, production in France, West Germany, Italy, and the United Kingdom together (hereafter referred to as "Europe") has so far advanced at less than half the rate of the American economy. Moreover, European employment remains virtually unchanged from what it was ten years ago despite the millions of new entrants into its labor force. Even the current recovery has not prevented European employment from declining. These European countries as a group now have an unemployment rate of eleven percent and double-digit unemployment for at least the next year seems likely.

Chart 1 plots the annual unemployment rates, for the U.S. and for Europe (including Belgium and the Netherlands). Measuring rates on a standardized basis makes across-country comparisons more useful. These rates have been adjusted to allow for differences in the way unemployment rates are calculated in different countries. The unemployment rate in the United States fell as we recovered from the 1973-1975 recession, rose as the economy contracted sharply in the early 1980 s, and again retreated appreciably as the current recovery continued. The European experi- ence has been markedly different. There, the unemployment rate rose in the wake of the first oil price shock in the mid-1970s, much as it did in the United States. But then, unlike in the United States, it continued to rise through the rest of the 1970 s even though overall European economic activity grew at only a slightly slower pace than economic activity grew here. As a result, when Europe's rate of unemployment rose after the second oil price shock, it was starting from an already high plateau by historical standards of five and one half percent. By 1982, the European rate had risen to nine percent and the modest recovery of output since has not been enough to keep the rate from continuing to climb.

The burden of this unemployment is not spread evenly across countries or across groups within countries. In the United Kingdom and the Low Countries, the rate is 13 percent or more. In the Scandinavian countries, it is less than half that. France, Germany, and Italy currently have rates in the 8-10 percent range. As is typical in industrialized countries, unemployment is particularly high among young people. In 1984, the youth unemployment rate in the U.S. was about 13 percent. By contrast, the youth unemployment rate in the United Kingdom, France, and Italy ranged from 20 to 35 percent.

\section{Different equilibrium unemployment rates}

These levels of unemployment in Europe are even more startling when we consider Europe's past unemployment experience. A country's unemployment rate at any time consists of the sum of its equilibrium unemployment rate and the deviation from that rate. The equilibrium rate is that observed when an economy is subject to neither excess aggregate supply nor excess aggregate demand. That equilibrium rate will be influenced by demographic shifts, government policies toward unemployment, the fluidity of labor markets, and other developments. Differences in these factors account for the variation in equilibrium unemployment rates across countries.

Historically, Europe has had much lower unemployment rates than the U.S. because of its lower equilibrium unemployment rate. Among Euro- 
pean countries, there are significant differences as well. Suppose we take the average unemployment rate from 1968 to 1973 in each country as a rough measure of its equilibrium unemployment rate. For the United States, this rate was 4.6 percent. In Italy, it was 5.7 percent. France and the U.K. had rates of 2.5 and 3.5 percent, while West Germany had an average unemployment rate of 1 percent. The weighted average rate for these countries (plus Belgium and the Netherlands) was 3 percent. Thus, at least until the early 1970s, we would expect (and did observe) European unemployment rates to be significantly lower than American rates on average. This means that the current unemployment rate abroad is about 8 percentage points above the normal rate.

Estimates of the current equilibrium unemployment rate for the United States hover around 6 percent. Thus the actual unemployment rate in the U.S. has been moving closer to its equilibrium level. If the U.S. unemployment rate were as much above its equilibrium level as Europe's rate is now, we would have a total unemployment rate of about 14 percent-higher than any other rate recorded since World War II.

\section{Wages and unemployment}

What accounts for this continual rise in European unemployment rates relative to American rates? Growth rates of total output here and abroad have been too similar to be the cause. One argument is that the increasing share of output devoted to (labor intensive) services is responsible for the relatively rapid growth in American employment. In the decade prior to 1982, the output of the private service sector (e.g., wholesale and retail trade, finance, transportation) grew rapidly -at approximately three times the rate of manufacturing. As a result, the ratio of private service employment to manufacturing employment grew by about one-quarter. Virtually the same sectoral shift happened in Europe. However, the shift in Europe occurred in a dramatically different way. In the U.S., the number of service jobs increased sharply while manufacturing employment held steady. In Europe, by contrast, service employment rose about 10 percent while manufacturing employment declined by about the same percentage.

One notable area where the American and European economies do differ is in the behavior of their real, or inflation-adjusted wages. European real wages have risen relatively since World War II. The recovery of the European economies after World War II presumably accounts for faster real wage growth for much of this period. However, with much of the adjustment completed by the early 1970 s and with similar growth rates of the capital stock and similar demographic developments in later years, real wages would be expected to grow at similar rates here and abroad. In fact, as Chart 2 shows, European real wages have continued to rise more rapidly than real wages in the United States. This differential existed in both manufacturing and in services. Over the most recent decade, the effect of the differential shown in Chart 2 was to raise European real wages by one-third relative to U.S. real wages.

This sizable advance in real wages may have been a powerful restraining force on European employment growth. Even though at first glance Europe has achieved impressive labor productivity growth, it has not been great enough to keep up with real wage growth. Presumably much of this productivity increase reflects the response of European business to rising real wage costs. Since they apparently have had little success in reducing real wages through wage bargaining, it would be natural for them to try to raise the average productivity of their workers in other ways. Two routes have been taken. The first has been to eliminate the least productive plants, jobs, and employees, thereby raising the average productivity of those remaining. The second has been to direct new investment in plant and equipment toward laborsaving processes.

Though both strategies lead to lower employment in the short run, they may have very different longer run implications. If real wages were to decline in the future, many of the plants and employees idled by the first strategy could be recalled into service. By contrast, once labor-saving capital is installed, even rather large real wage declines are unlikely to appreciably raise the number of workers employed in plants constructed or remodeled under the second strategy. This long-run, "capital deepening" effect is likely to become more serious the longer real wages remain too high, for as time passes firms can continue to invest in labor saving machinery both to add to their existing capital and to replace worn-out capital. 


\section{Causes and cures}

One explanation for high real wages in Europe is that nominal wages there have tended to rise commensurately with prices, regardless of the source of the rise in prices. In contrast, wages in the United States tend to respond relatively slowly to increases in prices. This relative sluggishness of American wages, which is so often cited as an impediment to disinflationary demand policies, proved to be beneficial in the wake of the aggregate supply shocks of the 1970 s. The fact that wages here rose little in response to the surge of the general price level after the dramatic oil price increases in the middle and late 1970s generated exactly the type of real wage reduction needed to moderate unemployment. The effective indexing inflation of European wages, by contrast, precludes precisely the type of real wage adjustment that "supply shocks," such as sudden energy price or productivity changes, call for.

We might still expect that after a decade of everrising unemployment, the European real wage would have begun dropping, thereby resuscitating employment. It hasn't. And unemployment continues to rise. This suggests that neither employees nor employers regard the large pool of unemployed labor as an effective alternative source of labor. Public policies toward labor markets may have contributed to such a perception. Increased restrictions on employee dismissal, for example, may have discouraged employment of labor and encouraged more capital-intensive production processes.

To date, there is not a consensus as to how much labor market policies and other factors have contributed to the increase in European unemployment. Two things seem clear however. First, ten years of very high European unemployment have neither eliminated nor illuminated the cause of that unemployment. And second, and perhaps more importantly, business, labor, and government policies pursued over the past decade also seem unlikely to cure Europe's unemployment problem.

James A. Wilcox

\section{Chart 1}

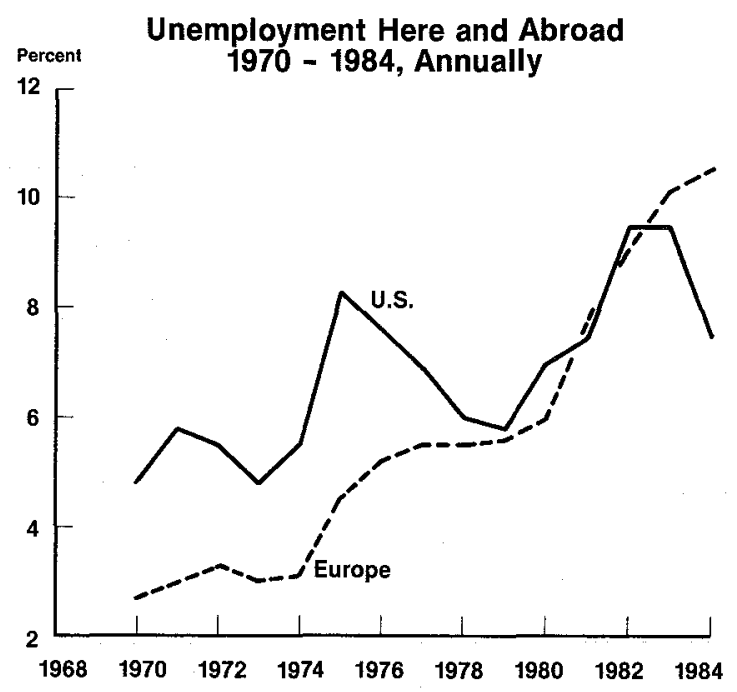

\section{Chart 2}

Real Wage Growth Here and Abroad 1974 - 1984, Annually

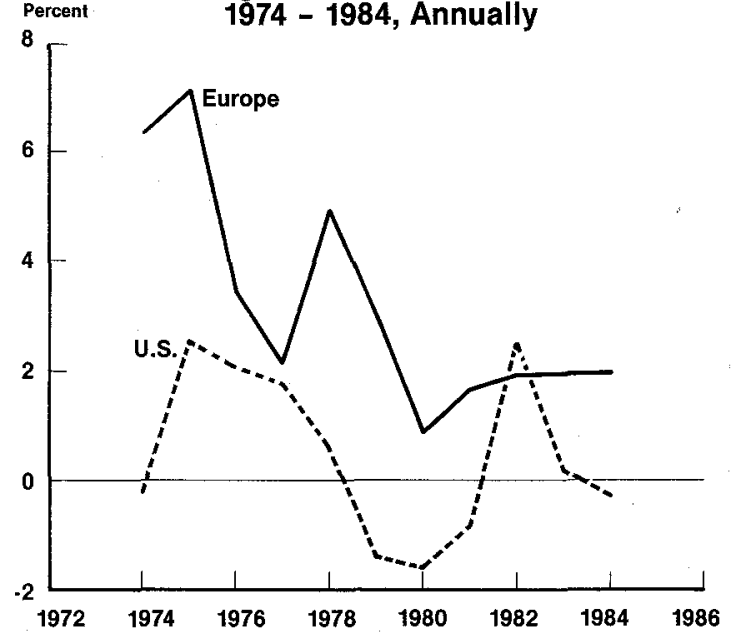

Opinions expressed in this newsletter do not necessarily reflect the views of the management of the Federal Reserve Bank of San Francisco, or of the Board of Governors of the Federal Reserve System.

Editorial comments may be addressed to the editor (Gregory Tong) or to the author ... . Free copies of Federal Reserve publications can be obtained from the Public Information Department, Federal Reserve Bank of San Francisco, P.O. Box 7702, San Francisco 94120. Phone (415) 974-2246. 
BANKING DATA-TWELFTH FEDERAL RESERVE DISTRICT

(Dollar amounts in millions)

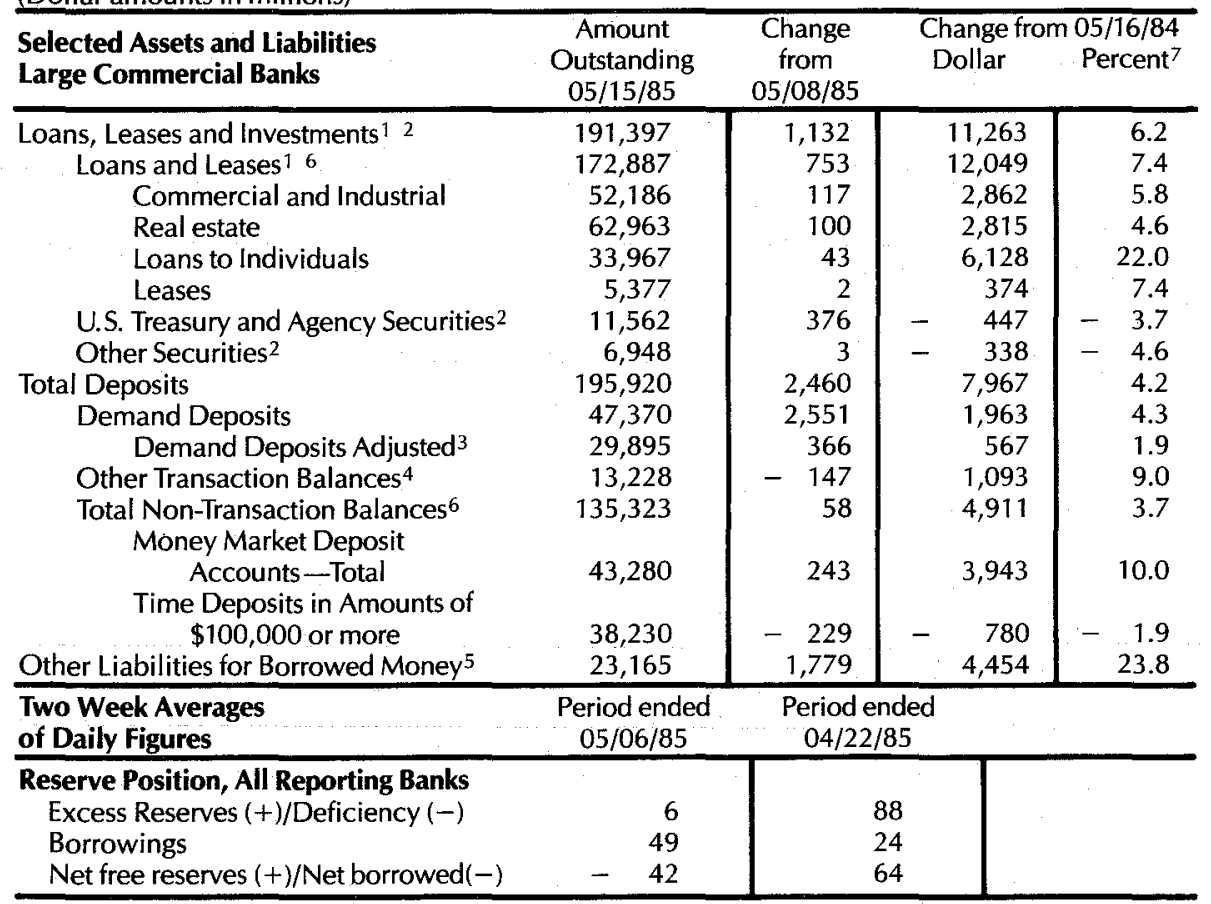

1 Includes loss reserves, unearned income, excludes interbank loans

2 Excludes trading account securities

3 Excludes U.S. government and depository institution deposits and cash items

4 ATS, NOW, Super NOW and savings accounts with telephone transfers

5 Includes borrowing via FRB, TT\&L notes, Fed Funds, RPs and other sources

6 Includes items not shown separately

7 Annualized percent change 